\title{
Social Work Challenge: Sex Workers and their Families in Prague and South Bohemia Region
}

\author{
S. Ondrasek (Stanislav Ondrasek)1, A. Kajanova (Alena Kajanova)'1, M. Kozubik \\ (Michal Kozubik)²
}

${ }^{1}$ Institute of Social and Special-pedagogical Sciences, Faculty of Health

\section{Original Article} and Social Studies, University of South Bohemia in Ceske Budejovice, Jirovcova 24, 37004 Ceske Budejovice, CZ

${ }^{2}$ Department of Social Work and Social Sciences, Faculty of Social Sciences and Health Care, Constantine the Philosopher University, Kraskova 1, 9401 Nitra, SK

\section{E-mail address:}

mkozubik@ukf.sk

\section{Reprint address:}

Michal Kozubik

Dept. of Social Work and Social Sciences

Faculty of Social Sciences and Health Care

Constantine the Philosopher University

Kraskova 1

94901 Nitra

SK

Source: Clinical Social Work and Health Intervention

Volume: 9

Issue: 2

Pages: $75-80$

Cited references: 20

\section{Reviewers:}

Gabriela Lezcano

University of California, San Francisco, USA

Daniel J. West, Jr.

University of Scranton, Department of Health Administration and Human Resources, USA

\section{Key words:}

Sex workers. Sex Business. Family. Relationships.

\section{Publisher:}

International Society of Applied Preventive Medicine i-gap

CSWHI 2018; 9(2): 75 - 80; DOI 10.22359/cswhi_9_2_11 @ 2018 Clinical Social Work and Health Intervention 


\section{Abstract:}

Objective: There is a lack of information related to women sex workers and their families in Prague and South Bohemia Region. We tried to explore how the relationship is between the women and their primary families.

Design: Qualitative and exploratory study.

Participants: 37 women working in private sex business in the South Bohemian Region and the Capital Prague (Czech Republic). The age structure of the women was 20-55 years; the average age was 27 year.

Methods: Questioning method, technique of biographic-narrative interview. The interviews were verbatim transcribed and after that analyzed in the Atlas. Ti PC program using grounded theory.

Results: The data analysis showed that the sexual workers came from various families with significantly disturbed relationships with them. The family does not know about the sex work.

Conclusion: The family environment can create sufficient support that Social Workers can use to work with sex workers.

\section{Introduction}

Recent accounts of sexual commerce have drawn attention to the proliferation of online and sexual consumption $(1,2)$. But there is a lack of information related to online sex workers and their families in Eastern European countries, especially in Czech and Slovak Republic. The present studies follow contemporary approaches to economic analysis of prostitution and makes use of the benefits that the Internet has brought to this type of service (3). Regushevskaya and Tuormaa (2014) tried to answer the question how do prostitution customers value health and position health in their expressions on online forums (4). Sexual issues related to the men who are active online also come under scrutiny (5). Most of these research was conducted as qualitative studies via internet.

Most of the current studies focus on violence against women and its vulnerability and health consequences (6). Intimate partner violence against women is also a huge problem in the refugee camps (7). There is a movement which tries to prevent violence against women (VAW). It defines seven steps that all have a word beginning with the letter P designating what needs to be done by all countries to deal with VAW. These are: (1) prevention, (2) protection against, (3) promoting awareness and adherence to non-discrimination and no VAW, (4) probing, (5) prosecuting, (6) punishing, and (7) providing redress for acts of violence against women. These recommendations could be apply into to Social Work with sex workers.

We systematically do research related to selected aspects of the sex trade and the lifestyle of women in the private sex business $(8,9,10)$. Topics include: Can a person stop "screwing"?

What was your first contact with the sex trade and how can a person hide their visits to sex workers? In the course of the analysis, we identified an additional category that featured in all the topics: "trophy collecting". The discussants perceive sex workers as a commodity to be purchased and subsequently evaluated. The discussants tended to compete among themselves to visit the most sex workers or to be first to visit the latest sex worker. 
Despite of above mentioned studies, there is a lack of information related to the families of women in sex business. Thus, we will look into the family life of these women. We try to explore how the relationship between them and their family members looks like and what is the opinion of family members about their work.

\section{Methods}

The study made use of qualitative research strategy with the questioning method and the technique of biographic-narrative interview. The research set included 37 women working in private sex business in the South Bohemian Region and the Capital Prague (Czech Republic). The women were approached through advertisements in web portals, either by phone or by email. The age structure of the women was 20-55 years, the average age was 27 years. Before the start of the interview, the respondents were informed of the study goals and of the subsequent use; at the same time, absolute anonymity in form of fictitious names was guaranteed to them. The data were collected from June 2016 to
December 2017. The interviews were recorded in a voice recorder, subsequently verbatim transcribed and after that analyzed in the Atlas.Ti PC Program. This article deals with sex workers and their relationships to their primary family. In our manuscript neither animals nor plants were studied. Human beings were studied in line with the Helsinki Declaration.

The data analysis made use of the grounded theory method; the transcribed interviews were first encoded with the help of open coding and, within categorization, the following categories were identified - relationships with primary family, family's reaction to work in sex business - and sub-categories - relationship with the mother and relationship with the father. After categorizing the codes, axial coding took place to find relations between the individual categories and codes, which are graphically represented through networking in form of a diagram, see Diagram 1 - Relationships with family.

\section{Results}

\section{Diagram 1 - Relationships with family}

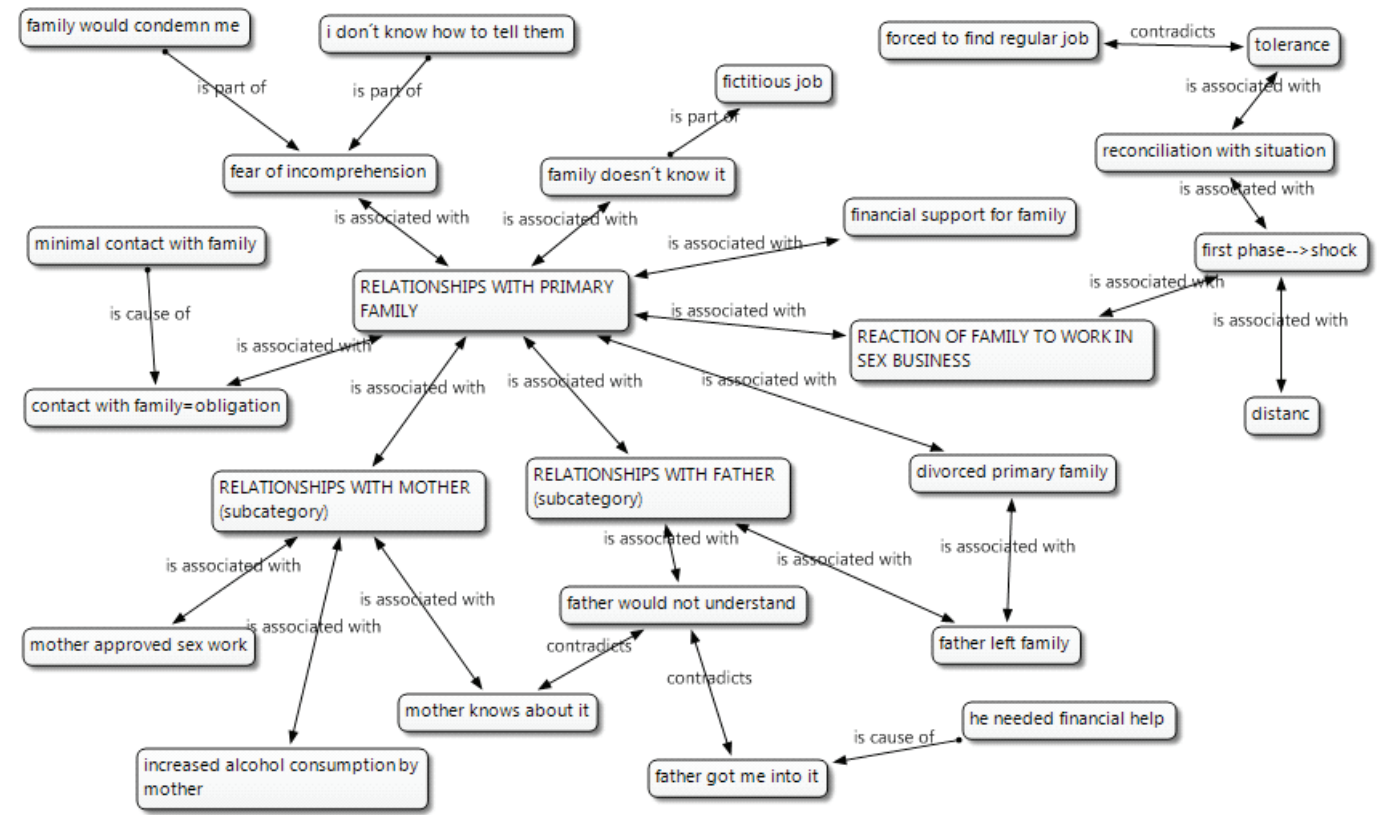

Source: GAJU 029/2016/S 


\section{Relationships with primary family}

The data analysis showed that the sex workers came from various types of families: divorced or married; that they have significantly disturbed relationships with their primary families. They often do not communicate with their families and are not in any other contact with them: "Most often I confide in my best friend who understands and supports me; I don't communicate with my family, so they don't know anything about me" (IN22, 30 years). "Nobody asks me. I don't communicate with my family" (IN31, 37 years).

Or they meet their family only in situations like birthdays of family members: "Once a year, at somebody's birthday or during Christmas" (IN4, 28 years), or just out of 'duty'. "Well, not much, sometimes when I have a free weekend I go to see them, but rather out of duty" (IN11, 36 years).

The overwhelming majority of the respondents answered no to the question whether their family knew about their work in sex business. That fact is related primarily to fear of incomprehension, of their family being ashamed of them or of condemning them: "No no, they would condemn me. They would think I am a whore. They would be ashamed of me. I don't want them to think that about me. They probably wouldn't understand that I do it for the money" (IN1, 43 years) "My family? Definitely not! My family would never understand this" (IN9, 26 years).

For that reason, the respondents make use of fictitious jobs to present before the family. The jobs are varied, from work in cosmetic or massage parlors to bartender to translator and interpreter. To have greater anonymity, the sex workers do not provide their services in their place of residence: "Well, they live quite far from here, so nobody can tell them in person" (IN12, 25 years); an exception is big cities with many inhabitants. A crucial measure to hide the work in sex business from the family includes the respondents' pictures presented in the ads without faces and taken at such places of the flat that cannot be identified; often the pictures are not of them but downloaded from the Internet.

A specific person mentioned by the respondents as not knowing about their work was their father; they also said they did not wish him to ever learn to know of it: "...dad doesn't know about it. H he wouldn't understand it" (IN4, 28 years), ,...primarily dad wouldn't cope with it. He would disinherit me" (IN9, 26 years). Paradoxically, the father may be the person who mediates the first contact with sex business: "My father, he even got me to sex business; I remember how he got me dancing in a cabaret which actually was a brothel with whores. I started dancing there, than making strip, and then I went to the room..." (IN8, 24 years).

\section{Reaction of the family to work in sex business}

If the respondents decide to confide in a family member, they primarily tell their mother: "Only mum knows it" (IN7, 24 years). Mum knows about it." (IN20, 22 years) who even may support the work in sex business:"

"My family knows it. My mum knows it. My children know it, and my mum finally said: If only I were younger" (IN5, 50 years).

The reaction of the family to their daughter working as a sex worker are varied according to the statements. In the first stage, the family copes with the shock; then conciliation and some tolerance come: " $A f$ ter some two years they (my family) saw that there was no use to resist (IN2, 23 years). "Well, my family tolerates it" (IN26, 36 years), but at the same time they insist on finding another job: "I was there yesterday and she asked if I kept doing my job. And 
I told her: "and what else should I do? Well, find another job" (IN2, 23 years).

If the family does not accept the work in the sex business after the first stage, another option can take place, specifically dissociation from the respondent. "With my family, no, they have dissociated from me" (IN14, 27 years).

\section{Discussion}

The respondents come from various family environments; therefore they cannot be considered a homogeneous group. The respondents rarely talked about their siblings; whether they had contact with them or whether they even had siblings. Sex workers and their social contacts were dealt with for example by Dalla (11); in her study, the sex workers talked about their family environment among other things; they perceived their relationships with their families mainly as bad; they also mentioned their parents ${ }^{6}$ problems with alcohol. We found a similar experience, i.e. increased alcohol consumption by the parents (primarily by the mother) in our study, too.

The respondents' families mostly do not know about their working in sex business; and the respondents do not wish them to know out of fear that their family would not understand them and condemn them. However, if a woman decides to confide in a family member with respect to the work in sex business, she usually confides in her mother. If the family learns to know about the respondent's work, they pass several stages: shock, denial, coping, conciliation and other stages described by Kübler-Ross (12) in the model of accepting changes.

One respondent said in an interview that she came to sex work for the first time due to her father's "getting" her to that work. The fact that a family member mediated the first contact with the sex business to the respondent is not rare at all, as Demleitner
(13) states. At the same time, for example according to the findings of Taiwan police, a half of the woman approached entered sex business due to pressure from the family (14). The women also often support their family financially through sex work (15), which was stated by some respondents in our study too.

There are a number of studies stating that sex workers were sexually abused, physically or mentally mistreated in childhood or adolescence $(16,17,18$ etc.). None of the respondents stated such thing in our study. On the other hand, a key factor, according to the Indian study by Chattopadhyay, Bandyopadhyay \& Duttagupta (19), is lack of support of the life style related to sex work by the family. Such lack of support may be manifested by failure to accept sex work and by disassociation of the family which could be seen here, too.

\section{Conclusion}

Private sex workers rarely visit social or health services because of fear of loss of anonymity; therefore Social Work rarely meets this target group. The family environment that can be included in the social network may create sufficient support that can be used by Social Workers when working with sex workers, primarily if a sex worker wants to leave the sex business (20).

\section{References}

1. HUBBARD P, COLLINS A, GORMANMURRAY A (2017) Introduction: Sex, consumption and commerce in the contemporary city. Urban Studies 54(3): 567-581.

2. SWANSON, E (2017) Freedom, Commerce, Bodies, Harm: The Case of Backpage.com. Social Inclusion 5(2): 3-15.

3. POKATOVICH EV, MATYUSHONOK VD (2017) Price Setting in Online Prostitution Market. Ekonomicheskaya Politika. 12(3): 222-235. 
4. REGUSHEVSKAYA E, TUORMAA T (2014) How do prostitution customers value health and position health in their discussions? Qualitative analysis of online forums. Scandinavian Journal of Public Health. 42(7): 603-610.

5. BECKHAM K, PROHASKA A (2012) Deviant Men, Prostitution, and the Internet: A Qualitative analysis of Men who killed Prostitutes whom they met online. International Journal of Criminal Justice Sciences. 7(2): 635-648.

6. ZAKALIYAT B, SUSUMAN, AS (2018) Factors of Domestic Violence Against Women: Correlation of Women's Rights and Vulnerability. Journal of Asian and African Studies. 53(2): 85-296.

7. WACHTER K et al. (2018) Drivers of Intimate Partner Violence Against Women in Three Refugee Camps. Violence against Women. 24(3): 286-306.

8. ONDRASEK S, RIMNACOVA Z, KAJANOVA A (2018) It's also a kind of adrenalin com-ition"-selected aspects of the sex trade as viewed by clients. Human Affairs 28(1): 24-33.

9. ONDRASEK S, KAJANOVA A (2017) “It is such a very free job." Selected aspects of the lifestyle of women in the private sex business. Kontakt. 19(1): 67-72.

10. RAC I, KOZUBIK M, MATEL A (2016) Violence against Roma women in intimate relationships. 16(6): 62-77.

11. DALLA, R. L (2001) Et Tú Brutè? A Qualitative Analysis of Streetwalking Prostitutes' Interpersonal Support Networks. Journal of Family Issues. 22(8): 1066-1085.

12. KUBHLER-ROSS, E (2015) About Death and Dying: What should people learn to die.
(About Death and Dying: What should people learn from dying). Praha: Portal.

13. DEMLEITNER, N. (1994) Forced prostitution: naming an international offense. Fordham International Law Journal. 18: 163-196.

14. MCCAGHY C. H, HOU C (1994). Family affiliation and prostitution in a cultural context: Career onsets of Taiwanese prostitutes. Archives of Sexual Behavior. 23(3): 251-265.

15. GADEKAR, U (2015). Socio-Economic Status and Health Challenges of Female sex Workers of Miraj Town, India. International Research Journal of Social Sciences. 4(6): 68-71.

16. GIOBBE, E (1991) Prostitution, Buying the Right to Rape, in Ann W. Burgess, (ed.) Rape and Sexual Assault III: a Research Handbook. New York, Garland Press.

17. BARRETT D, BECKETT W (1996). Child prostitution: reaching out to children who sell sex to survive. British Journal of Nursing. 5(18): 1120-1125.

18. MELISSA F, HOWARD B (1998). Prostitution, Violence, and Posttraumatic Stress Disorder. Women \& Health. 27(3): 37-49.

19. CHATTOPADHYAY M, BANDYOPADHYAY S, DUTTAGUPTA C (1994). Biosocial factors influencing women to become prostitutes in India. Social Biology. 41(3-4): 252-259.

20. FARLEY, M (2003). Prostitution, Trafficking and Traumatic Stress. UK: Psychology Press.

The article is an output of GAJU 029/2016/S project - Lifestyle of women in the private sex business and their (self-)reflections. 